Short communication

\title{
Occurrence of Cryptosporidium oocysts and Giardia cysts in water supplies of San Pedro Sula, Honduras
}

\author{
Helena María Solo-Gabriele, ${ }^{1}$ Arba LeRoy Ager, Jr., ${ }^{2}$ \\ John Fitzgerald Lindo, ${ }^{2}$ José María Dubón, ${ }^{3}$ Shondra Michelle \\ Neumeister, ${ }^{1}$ Marianna Karas Baum, ${ }^{2}$ and Carol Jean Palmer ${ }^{2}$
}

ABSTRACT During June 1996, water supplies of the city of San Pedro Sula, Honduras, were sampled to obtain an assessment of Cryptosporidium oocyst and Giardia cyst concentrations. Each sample was concentrated and stained with an indirect immunofluorescent antibody, and parasites were counted through microscopic analysis. In three surface water supplies, Cryptosporidium oocyst concentrations ranged from 58 to 260 oocysts per $100 \mathrm{~L}$, and Giardia cysts were present in concentrations ranging from 380 to 2100 cysts per 100 L. Unlike the surface water samples, groundwater had a higher concentration of Cryptosporidium oocysts (26/100 L) than Giardia cysts $(6 / 100 \mathrm{~L})$, suggesting that the groundwater aquifer protects the water supply more effectively from larger Giardia cysts. Cryptosporidium oocyst concentrations are within the typical range for surface water supplies in North America whereas Giardia cyst concentrations are elevated. Efforts should be made to protect raw water from sources of contamination.

The human gastrointestinal illnesses, cryptosporidiosis and giardiasis, are caused by the protozoan pathogens Cryptosporidium parvum and Giardia lamblia, respectively. Both diseases cause abdominal cramps, nausea, and watery diarrhea. For immunocompetent individuals the diseases are self limiting; however, for young children, the elderly, and immunocompromised populations they can be life threaten-

\footnotetext{
1 University of Miami, College of Engineering. Address correspondence to: H.M. Solo-Gabriele, College of Engineering, University of Miami, P.O. Box 248294, Coral Gables, Florida 33124-0630. email: hmsolo@miami.edu

2 University of Miami, School of Medicine, Coral Gables, Florida, USA (John Fitzgerald Lindo is now with the University of West Indies, Department of Microbiology, Mona, Kingston, Jamaica).

3 Social Security Hospital, San Pedro Sula, Honduras.
}

ing. There is no effective medical treatment for cryptosporidiosis. In immunocompromised individuals, cryptosporidiosis is characterized by several stools per day and tremendous fluid loss that lasts for months to years and can ultimately cause death $(1,2)$.

The transmission of cryptosporidiosis and giardiasis via contaminated water is well documented (3). Potential sources of oocysts and cysts in water supplies include wastewater of human origin and feces from many mammalian species, including cattle and beaver $(4,5)$. Both oocysts and cysts are capable of surviving environmental stresses and are resistant to conventional chlorine disinfection (6).

The country of Honduras, in Central America, is at high risk for increased morbidity and mortality from these gastrointestinal diseases because of the high prevalence of HIV among its population (7) and because treatment of its potable water supplies is generally limited to chlorination, if chemical disinfection processes are used at all. The city of San Pedro Sula, a major urban area of Honduras, was chosen for this investigation due to these elevated risks. Although the community monitors its water supplies for basic physical and chemical parameters, microbial monitoring is limited to total and fecal coliform. In general, groundwater is usually characterized by an absence of coliform bacteria whereas surface waters typically exhibit a few hundred fecal coliform per $100 \mathrm{~mL}$ solution. No water quality data were available for waterborne parasites, such as Cryptosporidium and Giardia 
spp., since water in this area has never been analyzed for these microorganisms. The purpose of this investigation was to make an initial assessment of the city's water supply with respect to Cryptosporidium oocysts and Giardia cysts in order to determine whether further study targeting these parasites is warranted.

As of June 1996, the municipal potable water system of San Pedro Sula consisted of five raw water sources, which supply a total of 140000 cubic meters per second to a population of approximately 400000 . Three of these sources are surface waters (Santa Ana, Piedras, and Zapotal Rivers) and the remaining two are groundwater supplies (Sunceri and Chamelecon wellfields). Treatment of each source varies considerably. The Santa Ana and Piedras Rivers are fitted with sedimentation basins at the raw water intake for purposes of settling coarse particles. After initial sedimentation at the river, the raw waters are piped to treatment plants. The Santa Ana plant is fitted with a conventional surface water treatment system which includes full alum coagulation processes (rapid mix, flocculation, and sedimentation) followed by rapid sand filtration. Disinfection is effected utilizing chlorine gas immediately prior to and after the filtration units. The Piedras River plant consists of a chlorine contact basin. The remaining three water sources receive considerably less treatment. The water from the Zapotal River receives chlorine treatment only, and the groundwater sources are untreated. Chlorine residuals $(1 \mathrm{mg} / \mathrm{L})$ are generally measurable throughout the distribution system except for areas on the northeast and southeast side of the city which receive most of their water from the untreated groundwater sources. Raw sewage is collected and discharged to canals which lie downstream from the river water intakes. The Sunceri wellfield lies within several hundred meters of these discharge canals.

In June 1996, raw water samples were collected at each of the five municipal water supplies except for the Chamelecon wells, since the water supply pumps were inoperative. A sample was also collected from a tap that receives chlorinated water from the Piedras River. Samples were collected and processed for parasite analysis following the protocols recommended by the U.S. Environmental Protection Agency (8). In brief, between 150 and $370 \mathrm{~L}$ of water were filtered through a $1 \mu \mathrm{m}$ nominal pore size yarn wound filter (Florida Filters, Miami, FL). From the three river sources, water was pumped using a submersible pump and generator system. Rate of flow for all samples was maintained at $3.7 \mathrm{~L} / \mathrm{min}$. Upon sample concentration, the filters were inserted inside two watertight bags and placed into a cooler with ice. The samples were processed within 24 hours at the University of Miami. A single pellet was obtained from each collected sediment sample using repetitive hand-washing, centrifugation, and percoll-sucrose purification. An aliquot (0.5 to $1.5 \mathrm{~mL})$ was then filtered through a membrane filter (Sartorius, Hayward, CA), stained with an indirect immunofluorescent antibody (Ensys Inc., Research Triangle Park, NC), mounted on slides, and examined under epifluorescence microscopy. Giardia cysts and Cryptosporidium oocysts were identified by their fluorescence, size, and morphology. Positive and negative controls were included for quality control.

Results (Table 1) show that among the rivers tested, the Santa Ana River had the highest concentrations of target organisms (2100/100 L Giardia cysts, 260/100 L Cryptosporidium oocysts) while the Zapotal River had the lowest
(240/100 L Giardia cysts, 44/100 L Cryptosporidium oocysts). There was a 0.5 and $1.2 \log _{10}$ removal of cysts and oocysts, respectively, between the Piedras River water supply and the domestic tap. In contrast to the river water sources, the groundwater supply (Sunceri Well \#4) had lower concentrations of Cryptosporidium and $\mathrm{Gi}$ ardia spp. and a shift in the relative distribution of these target organisms, with larger numbers of Cryptosporidium oocysts $(26 / 100$ L) than Giardia cysts $(6 / 100 \mathrm{~L})$.

The surface waters of San Pedro Sula were found to contain Giardia cysts at elevated concentrations (geometric mean, 580 oocysts $/ 100 \mathrm{~L}$ ) relative to reported values in North America $(9,10)$. Rose et al. reported a geometric mean of 3 cysts/100 L; LeChevallier and Norton in a similar comprehensive study of North American waters reported 280 cysts/100 L. On the other hand, Cryptosporidium oocyst concentrations in San Pedro Sula (geometric mean, 87 oocysts/100 L) were near average values typically observed in North American surface waters (Rose et al., 43 oocysts/100 L; LeChevallier and Norton, 270 oocysts $/ 100 \mathrm{~L}$ ).

Results also indicate surface water supplies had higher oocyst and cyst concentrations than the groundwater and tap water supplies tested, and the relative distribution of target organisms between surface and groundwater supplies was distinctly different. It is postulated that this reversal in the distribution of target organisms is due to the filtration capacity of the groundwater aquifer, which effectively removes larger Giardia cysts

TABLE 1. Results of water quality analyses, San Pedro Sula, Honduras, June 1996

\begin{tabular}{lccc}
\hline & & \multicolumn{2}{c}{ Concentration (No./100 L) } \\
\cline { 3 - 4 } \multicolumn{1}{c}{ Location } & Type of sample & Giardia cysts & Cryptosporidium oocysts \\
\hline Santa Ana River & Raw water & 2100 & 260 \\
Zapotal River & Raw water & 240 & 44 \\
Piedras River & Raw water & 380 & 58 \\
Sunceri Well \#4 & Raw water & 6 & 26 \\
Domestic tap & Chlorinated \& settled & 120 & 4 \\
& Piedras River water & & \\
\hline
\end{tabular}


while smaller Cryptosporidium oocysts are transported more efficiently toward the pumping well.

Although engineered treatment systems can reduce the number of Cryptosporidium oocysts and Giardia cysts after raw water is collected, efforts in San Pedro Sula should also focus on a watershed management plan aimed at reducing contamination of raw water sources. The watersheds that drain into the river supplies are characterized by mountainous dense tropical forests which are sparsely inhabited by squatters with makeshift homes that lack proper sanitation systems. As a result, potential sources of parasites to the river supplies include wild animals and human wastewater. The groundwater wells are located near rivers which receive untreated sewage. Contaminated water from these rivers can potentially impact wells in their vicinity.

A sanitary sewer collection system would improve the quality of the groundwater supply. A watershed management plan should focus on identifying and eliminating contaminant sources as well as documenting the water quality improvements associated with expansion of the community's sanitary sewerage system. A sampling plan should be implemented prior to and after such improvements to document such benefits. Ideally, implementation of such a plan should be coordinated with a clinical study to substantiate public health benefits.

Acknowledgments. The authors would like to thank Hazen and Sawyer, Inc. and Saybe and Associates for providing engineering documents on San Pedro Sula's sanitary infrastructure. Also we would like to recognize the cooperation received from San Pedro Sula's Municipal Division of Waters (D.I.M.A.), whose staff assisted with gathering information and sampling of water supplies.

\section{REFERENCES}

1. Grimason AM, Smith HV, Smith PG, Jackson ME, Girdwood RWA. Waterborne cryptosporidiosis and environmental health. Environ Health 1990;98:228-233.

2. Current WL, Garcia LS. Cryptosporidiosis. Clin Microbiol Rev 1991;4:325-358.

3. Solo-Gabriele HM, Neumeister S. U.S. outbreaks of cryptosporidiosis. Journal AWWA 1996:88:76-86.

4. Juranek DD. Cryptosporidiosis: Sources of infections and guidelines for prevention. Clin Infect Dis 1995;21,Suppl 1:S57-61.

5. Roach PD, Olson ME, Whitley G, Wallis PM. Waterborne Giardia cysts and Cryptosporid- ium oocysts in the Yukon, Canada. Appl Environ Microbiol 1993;59:67-73.

6. Korich DG, Mead JR, Madore MS, Sinclair NA, Sterling CR. Effects of ozone, chlorine dioxide, and monochloramine on Cryptosporidium parvum oocyst viability. Appl Environ Microbiol 1990;56:1423-1428.

7. Lindo JF, Dubon JM, Ager AL, de Gourville EM, Solo-Gabriele HM, Klaskala W, et al. Intestinal parasitic infections in HIV-positive and HIV-negative individuals in Honduras. Am J Trop Med Hyg 1998;58:431-435.

8. U.S. Environmental Protection Agency. Monitoring requirements for public drinking water supplies; Proposed rule. Fed Regist 1994:59:6416-6429.

9. Rose JB, Gerba CP, Jakubowski W. Survey of potable water supplies for Cryptosporidium and Giardia. Environ Sci Technol 1991;25: 1393-1400.

10. LeChevallier MW, Norton WD. Giardia and Cryptosporidium in raw and finished water. Journal AWWA 1995;9:54-68.

Manuscript received on 8 August 1997. Revised version accepted for publication on 17 September 1998.

RESUMEN Para estimar las concentraciones de oocistos de Cryptosporidium y quistes de Giardia en los abastecimientos de agua de la ciudad de San Pedro Sula, se examinaron muestras del agua en junio de 1996. Cada muestra se concentró y se marcó con un anticuerpo inmunofluorescente indirecto y los parásitos se contaron mediante análisis microscópico. En tres abatecimientos de agua, las concentraciones de oocistos de Cryptosporidium alcanzaron un recorrido de 58 a 260 oocistos por $100 \mathrm{~L}$, mientras que los quistes de Giardia se encontraron en concentraciones de 380 a 2100 quistes por $100 \mathrm{~L}$. Al contrario de las muestras de agua superficial, el agua subterránea tuvo mayor concentración de oocistos de Cryptosporidium (26/100 L) que de quistes de Giardia (6/100 L), lo que sugiere que el acuífero subterráneo protege mejor al abastecimiento de agua contra los quistes de Giardia, que son más grandes. Las concentraciones de oocistos de Cryptosporidium estuvieron dentro del recorrido típico de los abastecimientos de agua en Norteamérica, pero los de Giardia fueron más elevados. Deben tomarse medidas para proteger el agua sin depurar de las fuentes de contaminación. 